\title{
INDUSTRY 4.0: AN EMPLOYEE PERCEPTION (CASE OF THE CZECH REPUBLIC)
}

\author{
Nikola Soukupová ${ }^{1}$, Markéta Adamová1, Růžena Krninská1 \\ ${ }^{1}$ Department of Management, Faculty of Economics, University of South Bohemia in České Budějovice, Studentská 13,
37005 České Budějovice, Czech Republic
}

Link to this article: https://doi.org/10.11118/actaun202068030637

Received: 3. 2. 2020, Accepted: 20. 4. 2020

To cite this article: SOUKUPOVÁ NIKOLA, ADAMOVÁ MARKÉTA, KRNINSKÁ RŮŽENA. 2020. Industry 4.0: An Employee Perception (Case of the Czech Republic). Acta Universitatis Agriculturae et Silviculturae Mendelianae Brunensis, 68(3): 637-644.

\begin{abstract}
Considering the fact that the initiative Industry 4.0 started in the Czech Republic in 2016, it is still a relatively unexplored topic. However, there is a significant lack of researches, which examines the perception of Industry 4.0 by employees whose jobs are directly threatened by Industry 4.0. The aim of the paper was found out how Czech employees perceive Industry 4.0 and whether a general pattern can be created for a group of employees who perceive it as a potential threat to their existence based on their characteristics (age, gender, education, and the job position). Information about this initiative is often tendentiously presented by media, even managers don't have precise information about the benefits and outcomes of Industry 4.0. Industry 4.0 from the employees' point of view is connected with job loss or substitution of human work by robots. And this state might build barriers to implementation Industry 4.0.
\end{abstract}

Keywords: initiative industry 4.0, social impact of Industry 4.0, employees, Czech Republic, discriminant analysis, large companies, production

\section{INTRODUCTION}

In the past, the industry has been influenced by technological change and innovation. These paradigms are referred to as industrial revolutions (Lasi et al., 2014). At the moment, we are on the edge of other industrial revolution, the fourth one, referred to as Industry 4.0, which will come in a few next decades (Syam and Sharma, 2018). Industry 4.0 is still an emerging topic in management studies (Piccarozzi et al., 2018). The beginning of the fourth industrial revolution is an unrepeatable moment of human history and will benefit those individuals who will understand, accept, and use these changes (Kraftova et al., 2018). Industry 4.0 leads to a trend toward new business processes and e-commerce (Hitpass and Astudillo, 2019). Extensive use of automation, robotics, and digitization will have serious implications for jobs, skills, and occupations. Industry 4.0 development will be accompanied by a change in tasks and requirements for people in the factory (Gorecky et al., 2014; Sumer, 2018). According to Ministry of Labour and Social Affairs (2016) Industry 4.0 will offer many opportunities, but its threats, such as the lack of management structural changes within the labor market, and the social and ethical dimensions of Industry 4.0 implementation, must not be forgotten. Therefore, it would be necessary for enterprises to empower their employees into changes that accompanying Industry 4.0. To prepare the entire concept of Human resource management, including personnel policies and activities for changes in connection with Industry 4.0, and to inform all employees. The biggest challenge of Industry 4.0 is not technology - it's the people. Almost one-fourth of enterprises believe that uncertainty impact on the workforce will have an important impact in the next five years (Deloitte, 2017). 
The initiative Industry 4.0 is worldwide phenomena, which is bringing changes (mainly digitization) to countries, regions, cities, businesses, and enterprises. However only individual persons with their capabilities will have to face this global, economic and social revolution and their approach will decide about successful implementation. Because enterprises need engaged employees to transform the enterprise forward to Industry 4.0. It will enable efficient interaction between humans and the new Industry 4.0 business environment. Even Stentoft et al. (2019) highlight a lack of knowledge about Industry 4.0, trust and employee readiness as barriers for Industry 4.0.

The aim of the paper was found out how Czech employees perceive Industry 4.0 and whether a general pattern can be created for a group of employees who perceive it as a potential threat to their existence based on their characteristics (age, gender, education, and the job position).

\section{Initiative Industry 4.0}

The term "Industry 4.0" - internationally known as the Industrial Internet of Things (Müller and Däschle, 2018) or Industrial Internet Lezzi et al. (2018) or also known as smart manufacturing (de Sousa Jabbour et al., 2018), was created by the German Federal Government in connection with its high-tech technology in 2011 and describes the integration of all value-added business divisions and the value-added chain with help of digitization (KPMG, 2016). Although Industry 4.0 is originally a German project, it must be understood, that it has a global character and horizontal networking of the value chain added will not be limited to just one enterprise or country (Rodic, 2017). Ding (2018) added, that the USA, Japan, and China successively implemented their plans for the industrial revolution. For example, the even European Member States and regions have committed to adapt their innovation systems to trends of Industry 4.0 (Ciffolilli and Muscio, 2018). The aim of Industry 4.0 is the creation of smart factories with the highest level of operational productivity, the efficiency of automation (Lu, 2017; Rodriguez-Salvador and Mancilla-de-la-Cruz, 2018).

Due to Industry 4.0, the concept of the job will change in the future. It will disappear some jobs and become new occupations. About 65\% of today's children will work in professions that we don't know. The proportion of robotics, the digitization of the economy, the share of employees in services, the health sector will grow. Unfortunately, the problems are related, and by 2025 an estimate of 140,000 jobs should be lost (Hedvicakova and Svobodova, 2017). On the other side, many jobs will emerge, but they will appear in other sectors, occupations and they will require new capabilities (Masarova, Korbos and Strunz, 2018). This is also evidenced by Kazancoglu and Ozkan-Ozen (2018), who add that due to the increasing complexity and intelligence in Industry 4.0 there is a need for employees who have multidimensional aspects.

The disappearing of job position due to robotics is not yet remarkable, although some countries even consider robot tax (Shiller, 2017). Research shows the complementary relationship between employment and robotics, but the substitution relationship between working time and robotics. The results also show the effects of the size of the enterprise and the proportion of production employees and auxiliary employees, etc. These findings suggest that the degree of robotics may vary depending on many factors of the labour market (IFR, 2016)

According to Manpower (2017), 90\% of employers expect a certain impact of digitization and automation over the next two years and the associated need for new knowledge and skills. However, 64\% of respondents do not expect significant changes, 19\% of enterprises expect staff growth and $12 \%$ of companies expect the decline of employees. The Czech Republic has a neutral attitude towards the Industry 4.0.

Our government approved also the initiative Industry 4.0 in 2016, whose long-term goal is to maintain and strengthen the competitiveness of the Czech Republic at the time of the so-called fourth industrial revolution. Leaders in this area include Germany. Robotics and automation in the Czech Republic are the fastest in the automotive and electrotechnical industry or services. Overall, the Czech Republic is at the beginning of the way to Industry 4.0 (Czech News Agency, 2017).

Industry 4.0 must be part of a very extraordinary socio-economic configuration and its threats are, among other things, unexpected consequences of automation, security uncertainty, etc. (Kovacs, 2018). According to the Ministry of Labour and Social Affairs (2016), between factors that threaten Industry 4.0 belongs: the neglecting of social and ethical impacts and the threat of the labour institute without creating conditions for job creation, including the failure to structural changes within labour market; which may lead to increased income disparities and the emergence of different barriers.

Even Gunasekaran et al. (2018) understand the human aspect of Industry 4.0 as a key component. Botha (2018) ranks among the dimensions of Industry 4.0 employees. Badri et al. (2018) talk about so-called Human-Machine Cooperation. So the focus of our research is on employees and perceptions of the social side of Industry 4.0.

The most similar research to our study was Basl (2017). But he solved mainly the level of knowledge about Industry 4.0, not perceiving by employees and respondents are mainly managers.

\section{MATERIALS AND METHODS}

In this quantitative research, a total of 435 opinions by employees of large enterprises were collected using a random selection procedure. The 
I: Other similar research to our study

\begin{tabular}{|c|c|c|c|}
\hline Hecklau et al. & 2016 & $\begin{array}{l}\text { It shows an approach to how enterprises can } \\
\text { make use of competencies to meet arising } \\
\text { challenges in Industry } 4.0 \text {. }\end{array}$ & $\begin{array}{l}\text { They created the model of competencies for } \\
\text { Industry } 4.0 \text {. }\end{array}$ \\
\hline Basl & 2017 & $\begin{array}{l}\text { The aim was to analyse the level of basic } \\
\text { knowledge of this topic in enterprises, the } \\
\text { existence of appropriate strategies, responsible } \\
\text { persons, and the general awareness among } \\
\text { employees (focused on management). }\end{array}$ & $\begin{array}{l}40 \% \text { is dealing with Industry } 4.0 \text { more than } \\
\text { a year, } 20 \% \text { are trying to implement the } \\
\text { initiative, } 20 \% \text { have known it, but do not have } \\
\text { implemented, } 8 \% \text { have no idea about content } \\
\text { and } 12 \% \text { have never met this term. }\end{array}$ \\
\hline Grzelczak et al. & 2017 & $\begin{array}{l}\text { Concentrated on the development of } \\
\text { competencies within Industry 4.0. }\end{array}$ & The relevance of soft skills is increasing. \\
\hline $\begin{array}{l}\text { Wilkesmann } \\
\text { and Wilkesmann }\end{array}$ & 2018 & $\begin{array}{l}\text { It provides case studies for different stages } \\
\text { of the organizing continuum in the context } \\
\text { of Industry } 4.0 \text {. }\end{array}$ & $\begin{array}{l}\text { The digitalization organizes a work } \\
\text { environment that must be supported by highly } \\
\text { qualified humans. }\end{array}$ \\
\hline Birkel et al. & 2019 & $\begin{array}{l}\text { The study aimed to identify the risks that arise } \\
\text { within the framework of Industry } 4.0 \text {. }\end{array}$ & $\begin{array}{l}\text { They identified economic, IT and technical, } \\
\text { ecological, political and social risks (e.g. job loss). }\end{array}$ \\
\hline Stentoft et al. & 2019 & Focused on readiness on Industry 4.0 of SMEs & They identified low degree readiness. \\
\hline
\end{tabular}

Source: own research

questionnaire contented characteristics information about respondents and questions focused on the Industry 4.0, its perceiving, knowledge of respondents, etc. Respondents were employees in large manufacturing enterprises within different management levels. The questionnaire was anonymous. Data was gained in the years 2017-2018. The research was focused on large manufacturing enterprises, respectively enterprises with their economic activity fall into group C (10-33): Manufacturing according to CZ NACE. The official definition of their activity is, therefore, the mechanical, physical or chemical conversion of materials or components into new products (goods).

The focus on selected economic activity is based on the assumption that production is a key segment of the fourth industrial revolution, as well as its further used Industry 4.0 (Ministry of Labour and Social Affairs, 2016). And the assumption that changes accompanying Industry 4.0 will be primarily concentrated in the area of manufacturing enterprises in the first wave (Deloitte, 2017; EY, 2016). The selection of only large enterprises included in the analysis was deliberate. The selection of enterprises was defined according to such criteria; the number of employees - more than 250 (EU Commission Report, 2012). As it was mentioned the first wave of changes in Industry 4.0 will concern large companies that are significantly more advanced in the integration of their production plans and have a higher level of automation and better financial opportunities than small and medium-sized enterprises (Institut der Deutschen Wirtschaft Consult, 2015). Sevinç et al. (2018) add that despite the benefits of Industry 4.0, small businesses have rather bad experiences with this initiative. And small and medium-sized enterprises often face different challenges and barriers than larger enterprises (Mittal et al., 2018).

According to information of the Czech Statistical Office (last update 1 January 2017), 12,051 business entities were registered within the Czech Republic, whose industry (economic activity) according to CZ NACE was category C - Manufacturing. There are in total of 866 enterprises meeting both selected categories (enterprise size and selected economic activity) within the Czech Republic.

In the process of discriminant analysis, we have developed a prognostic model for the group assigned. This model builds (if there are more than two groups, the model builds a set of discriminatory functions) in the form of a linear combination of predictor variables. Ensures the best distribution of groups. These functions are created by a set of observation results for which their group membership is known. In the future, these features can be used in new observations with known prediction variables and an unknown group. For each variable was found statistics: mean values, standard deviations, onedimensional variance analysis for each variable (Box test $\mathrm{M}$, in-group correlation matrix, intragroup covariation matrix, matrix covariance for matched groups, matrix of general correspondence). For each canonical discriminant function, it was calculated the following: custom value, scatter percentage, canonical correlation, Wilks's lambda, Chi-square and for each step prior probability, Fisher coefficients, non-standardized Wilks's lambda constants for each canonical function.

The discriminate analysis enables the evaluation of differences between two or more subject groups 
that are characterised by a certain number of features. Such evaluation provides a base of classification that builds on it. If the discriminate analysis is applied for predicting future economic footing of companies, the subjects are firms that are structured into two groups of prosperous firms and those in jeopardy of default. Each firm is characterised by a definite number of quantitative variables called discriminators.

From the obtained data (besides the basic descriptive statistics, the current state of the Industry 4.0 survey was investigated in the case of Czech employees in manufacturing companies) a discriminatory analysis was used, which was used to create a general prescription, respectively it classifies the objects into one of the existing groups (classes).

Barka (2003) states that in a discriminant analysis we assume that for each class (nominal value) ct, $t=1, T$, there exists (discriminant) function $f t$, such that:

$f t(X)=\max f k(X), \mathrm{k}=1, \ldots, \mathrm{T}$,

just when $X=\left[x_{1}, x_{2}, \ldots, x_{m}\right]$ belongs to the ct class. Assuming a normal course, the search for a discriminant function is limited to estimating the mean value $\mu \mathrm{i}$ (based on selection parameters) and covariance matrices Si (based on sample scattering). It is also appropriate to have the same covariance matrix predictors in each group.

It can be said, therefore, that the discriminant analysis examines the dependence between a certain number of independent variables (discriminators) and one dependent variable of a qualitative character. Classification of objects in discriminant analysis is based on assumptions about the properties of classification objects when these characteristics were determined by a questionnaire survey with respondents. Behind the independent variables $\left(x_{1}-x_{4}\right)$ the following characters of the addressed employees were selected:

- $x_{1}$ - age,

- $x_{2}$-gender,
- $x_{3}$ - job position,

- $x_{4}$ - the level of education.

And the dependent variable was chosen according to the question from the questionnaire. It was the question focused on the perceiving of Industry 4.0 by the respondent.

O - Industry 4.0 as a threat of job position (dependent variables):

- Yes $=1$,

- $\mathrm{No}=0$.

After verification of normality, we tested another assumption, namely the conformity of the covariance matrix. Since the two assumptions of discriminatory analysis were fulfilled, the analysis itself was proceeded. Its results are described in the next section of the paper.

\section{RESULTS}

The first question of the questionnaire survey was focused on the identification of the subjective perception of Industry 4.0 by respondents. It was found that $64 \%$ of respondents perceived Industry 4.0 as a potential threat. Only $36 \%$ of them answered resolute no on this question.

Based on the results of the descriptive statistics, we obtained the profile threaten employees.

Within the next question of the questionnaire survey was found the elementary knowledge of respondents about Industry 4.0. Whole 60\% of respondents are able to characterize Industry 4.0 and it is obvious that employees understand the issue in general terms.

After the basic descriptive statistic, it was continued with evaluation by discriminant analysis. This statistical method was used to create a general prescription for the group of employees who Industry 4.0 perceive as a potential threat to their existence based on their characteristics (age, gender, level of education and job position).

The method of discriminant analysis allows the identification of variables included in the analysis, anyway, the findings which of the examined

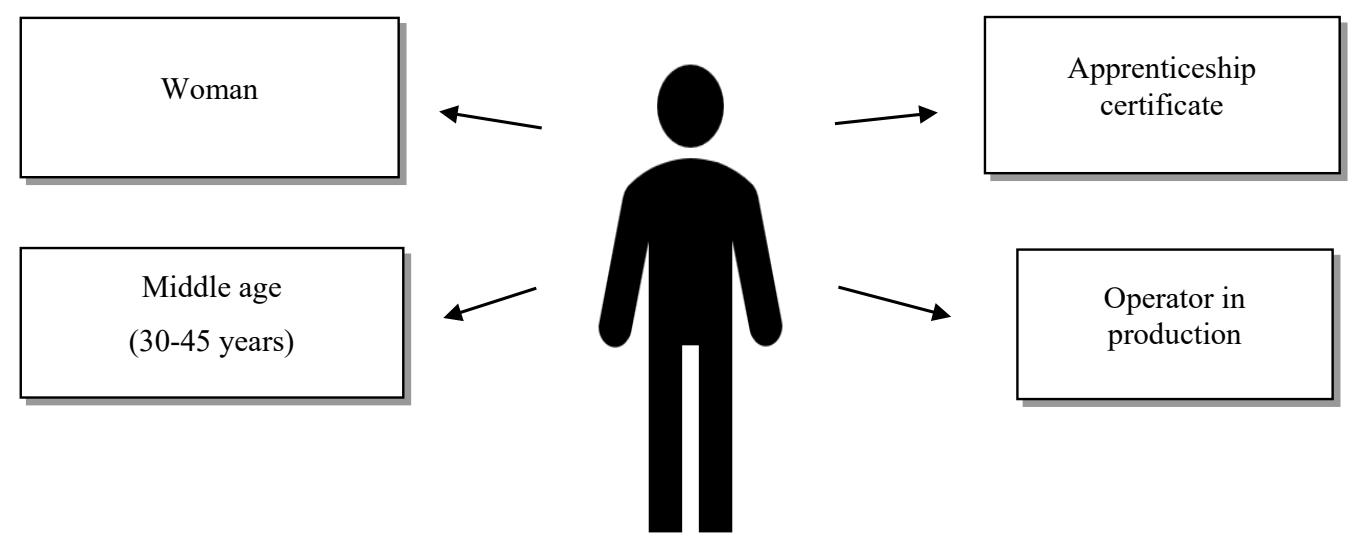

1: Profile threaten employees Source: own research 
features are significant or insignificant for inclusion in the individual groups surveyed.

It was therefore determined whether the respondent's gender, age, job position and level of education have a statistical effect on the respondents consideration - if they perceive Industry 4.0 as a threat to their job position or not.

It proved that only variables $x_{1}$ and $x_{2}$, i.e. age and gender, are significant for discrimination. On the other hand, the $x_{3}$ and $x_{4}$ variables, i.e. job position and level of education, are not relevant for group assignment. We use the classification functions to obtain coefficients of linear discriminant analysis of the included variables. We compile equations of discriminant functions for both groups, i.e. for respondents who perceive Industry 4.0 as a threat to their existence, as well as for respondents who do not perceive it as a threat.

The equations are:

- For first group, i.e. $\mathrm{O}=0$ ("Industry 4.0 is not threat"):

$$
L\left(k_{0}(x)\right)=0.506 x_{1}+1.483 x_{2}-12.884 .
$$

- For second group, i.e. $\mathrm{O}=1$ ("Industry 4.0 is threat"):

$$
L\left(k_{1}(x)\right)=0.985 x_{1}+1.603 x_{2}-26.023 .
$$

The probability of correct classification based on linear analysis is $86 \%$. The success rate of the discriminant function for the first group is $90 \%$ and for the second group $81 \%$.

\section{DISCUSSION}

Thus, initiative Industry 4.0 as a threat is perceived by middle-aged women (30-45 years old) working as an operator in the production and who have an apprenticeship certificate. This follows the research of Birkel et al. (2019), who says that there will be different competencies in the future and only highly qualified employees will be successful at labour market and "... unskilled labor force might not find a job anymore.” (Birkel et al., 2019, p. 7).

Although many employees feel be threatened by Industry 4.0, according to current analysis it is not supported; e. g. impact of Industry 4.0 on German production is related to growth. The employment rate will be increasing by $6 \%$ in the next 10 years, in manufacturing. The demand for employees may increase over the same period even by 10\% (Rüßmann et al., 2015). On the other side says Fonseca (2018, p. 392): "Employees with low skill levels risk becoming replaceable unless they are retrained, but those with the right competencies (creativity, decision-making skills, and technical and ICT expertise) will have more autonomy and interesting work." Employees gain information about Industry 4.0 from press and internet news mainly in the context of robotics and the loss of their jobs.
Their fear is based on negative information. If the enterprise would like to implement Industry 4.0 it will be necessary to develop employees' knowledge about the topic. But predictions are positive: e. g. In Germany, there will be an increase of 350,000 jobs through 2025 (Summer, 2018). According to the report of the National Observatory of Employment and Training: Impacts of Industry 4.0 on the Labor Market in the Czech Republic (2017), the prediction is following - robotics replacing especially professions that have a routine character and which are associated mainly with low qualification requirements and automation will reduce some non-routine activities in the case these activities can be algorithmized and standardized. However, the workforce will gradually be relocated to the service sector (servitization of the economy). According to Manpower (2017), only 12\% of employers worldwide believe that digitization will cause loss the jobs. Czech employers even expect an increase in jobs between 1-10\%. In Germany, for example, an average of 2 jobs have been cancelled due to the implementation of 1 robot into enterprises. However, there has been no increase in unemployment, but a shift of workforce into the service sector (Duspivova, 2019). OECD (2018, p. 7) "estimates suggest that about 14\% of employees are at a high risk of having most of their existing tasks automated over the next 15 years. Another 30\% will face major changes in the tasks required in their job and, consequently, the skills required."

More than half of the respondents can explain the term Industry 4.0, employees are not able to find out the advantages of the changes and even managers are not sure about Industry 4.0. But this result might not be significant. The high score could be caused by only gaining limited information from the media. Thus, respondents are not able to find out the advantages of the changes which Industry 4.0 brings. Even managers are not sure about this topic. Basl (2017) showed that only $12 \%$ of respondents never heart the concept a $37.5 \%$ managers evaluated as a reason for not implementation unclear benefits and $75 \%$ even little awareness. That proved the next research, which adds that managers understand the scope of Industry 4.0 but they are not able to get benefit from them (Deloitte, 2017).

The respondent's gender, age have a statistical effect on the respondents perception of Industry 4.0. Women are a more threatened group in the labor market women compared to men. Underemployment and lower levels of IT literacy are more common among women. Women are less likely to choose technical disciplines as their field, whose graduates are in high demand on the labor market and are expected to increase further in the future (World Economic Forum, 2016; Ministry of Labour and Social Affairs, 2016). 


\section{CONCLUSION}

Based on the discriminant analysis, it was found the pattern for employees who perceive Industry 4.0 as a threat and for employees who don't perceive as a threat. Only the age and the gender of the respondent are significant for analysis.

Based on the questionnaire survey, it was found that 280 respondents (representing 64\% of the respondents) perceived Industry 4.0 as a potential threat to their job position, while almost 174 respondents (40\% of the respondents) were not able to characterize Industry 4.0.

The most threatened group of Industry 4.0 belongs a woman in the middle age of (30-45) who works as an operator in production with an apprenticeship certificate.

Because the initiative Industry 4.0 started generally in 2011 and in the Czech Republic it started in 2016 (when the Ministry of Industry and Trade issued an initiative to maintain its competitiveness), it is still a relatively unexplored topic. The initiative itself (Ministry of Labour and Social Affairs, 2016) is rather a general recommendation in the context of the state of the Czech economy and the state of the technology and equipment of the industry. However, there is a significant lack of a research study to examine the perception of Industry 4.0 by employees whose jobs are directly threatened by Industry 4.0. Many studies are focused on companies' perceptions and managers' opinions. Our research was focused only on the area of production and on large enterprises, who will first invest in the implementation of Industry 4.0. Just focusing on only large companies can be limited of our study.

We believe that this article may be the basis for further research into which small and medium enterprises should be included and the topic will be analysed in all sectors.

In conclusion, Initiative Industry 4.0 is still a relatively unexplored field. Mainly from the perspectives of threatened employees. Information about this initiative is often tendentiously presented by media, even managers don't have precise imagination about the benefits and outcomes of Industry 4.0. Industry 4.0 from the employees' point of view is connected with job loss or substitution of human work by robots. And this state might build barriers to implementation Industry 4.0 in the Czech Republic.

\section{Acknowledgements}

The paper was supported by Faculty of Economics, the University of South Bohemia in České Budějovice within the project IGS28C1: "Vzájemné vazby v systému BSC v rámci ř́zení podniku.”

\section{REFERENCES}

BADRI, A., BOUDREAU-TRUDEL, B. and SOUISSI, A. S. 2018. Occupational health and safety in the industry 4.0 era: A cause for major concern? Safety Science, 109: 403-411.

BARKA, P. 2003. Knowledge discovery in databases [in Czech: Dobýváníznalostíz databází. Praha: Academia. BASL, J. 2017. Pilot study of readiness of Czech companies to implement the principles of Industry 4.0. Management and Production Engineering Review, 8(2): 3-8.

BIRKEL, H. S., VEILE, J. W., MÜLLER, J. M., HARTMANN, E. and VOIGT, K. I. 2019. Development of a Risk Framework for Industry 4.0 in the Context of Sustainability for Established Manufacturers. Sustainability, 11(2): 384.

BOTHA, A. P. (2018). Rapidly arriving futures: future readiness for Industry 4.0. South African Journal of Industrial Engineering, 29(3): 148-160.

BÜTH, L., BLUME, S., POSSELT, G. and HERRMANN, C. 2018. Training concept for and with digitalization in learning factories: An energy efficiency training case. In: Advanced Engineering Education \& Training for Manufacturing Innovation. $8^{\text {th }}$ CIRP Sponsored Conference on Learning Factories (CLF 2018). Vol. 23, pp. 171-176.

CIFFOLILLI, A. and MUSCIO, A. 2018. Industry 4.0: national and regional comparative advantages in key enabling technologies. European Planning Studies, 26(12): 2323-2343.

CZECH STATISTICAL OFFICE. 2019. Czech Statistical Office. [Online]. Available at: https://www.czso.cz/ csu/czso/udaje-o-zakladnim-souboru-4rbwnsn3b [Accessed: 2019, June 1].

CZECH NEWS AGENCY. 2017. Onset Industry 4.0 in the Czech Republic is the fastest in the automotive industry [in Czech: Nástup Průmyslu 4.0 je v ČR nejrychlejší v autoprůmyslu]. České noviny. [Online]. Available at: http://www.ceskenoviny.cz/zpravy/nastup-prumyslu-4-0-je-v-cr-nejrychlejsiv-autoprumyslu/1517972 [Accessed: 2019, June 1].

DE SOUSA JABBOUR, A. B. L., JABBOUR, C. J. C., GODINHO FILHO, M. and ROUBAUD, D. 2018. Industry 4.0 and the circular economy: a proposed research agenda and original roadmap for sustainable operations. Annals of Operations Research, 270(1): 273-286. 
DELOITTE. 2017. Industry 4.0: Are you ready for the next revolution? [in Czech: Průmysl 4.0: Jste připraveni na další revoluci?]. Deloitte. [Online]. Available at: https:/www2.deloitte.com/cz/cs/ pages/consumer-and-industrial-products/articles/prumysl-4-0-jste-pripraveni-na-dalsi-revoluci. html. [Accessed: 2019, June 1].

DING, B. 2018. Pharma industry 4.0: Literature review and research opportunities in sustainable pharmaceutical supply chains. Process Safety and Environmental Protection, 119: 115-130.

DUSPIVOVA, K. 2019. Robotization does not lead to rising unemployment, according to German practice [in Czech: Robotizace nevede $\mathrm{k}$ růstu nezaměstnanosti, ukazuje to německá praxe]. Trexima. [Online]. Available at: https://www.trexima.cz/aktualita/robotizace-nevede-k-rustunezamestnanosti-ukazuje-to-nemecka-praxe [Accessed: 2019, June 27].

EUROPEAN COMMISSION. 2012. Economy, finance and the euro publications. European Commission. [Online]. Available at: http://ec.europa.eu/economy_finance/publications/european_economy/2012/ index_en.html [Accessed: 2019. June 1].

EY. 2016. Industry 4.0 from the perspective of Czech practice [in Czech: Průmysl $4.0 \mathrm{z}$ pohledu české praxe]. ANZDAOC. [Online]. Available at: https://anzdoc.com/prmysl-40-z-pohledu-eske-praxelistopad-2016.html [Accessed: 18 April 2019].

FONSECA, L. M. 2018. Industry 4.0 and the digital society: concepts, dimensions and envisioned benefits. Proceedings of the International Conference on Business Excellence, 12(1): 386-397.

GORECKY, D., SCHMITT, M., LOSKYLL, M. and ZÜHLKE, D. 2014. Human-machine-interaction in the industry 4.0 era. In: $12^{\text {th }}$ IEEE International Conference on Industrial Informatics (INDIN). 27-30 July 2014, Porto Alegre, Brazil, pp. 289-294.

GRZELCZAK, A., KOSACKA, M. and WERNER-LEWANDOWSKA, K. 2017. Employees competences for Industry 4.0 in Poland-preliminary research results. In: $24^{\text {th }}$ International Conference on Production, July 30-August 3 2017, pp. 139-144.

GUNASEKARAN, A., SUBRAMANIAN, N. and NGAI, E. 2018. Quality management in the $21^{\text {st }}$ century enterprises: Research pathway towards Industry 4.0. International journal of production economics, 207: 125-129.

HECKLAU, F., GALEITZKE, M., FLACHS, S. and KOHL, H. 2016. Holistic approach for human resource management. In: $6^{\text {th }}$ CIRP Conference on Learning Factories. Vol. 54. Elsevier, pp. 1-6.

HEDVICAKOVA, M. and SVOBODOVA, L. 2017. Labor market of the Czech Republic in the context of Industry 4.0 [in Czech: Trh práce české republiky v kontextu průmyslu 4.0]. In: Sborník př́spěvků XX. mezinárodní kolokvium o regionálních vědách. 14.-16. června 2017. Brno: Masarykova univerzita, Ekonomicko-správní fakulta, pp. 303-310.

HITPASS, B. and ASTUDILLO, H. 2019. Industry 4.0 Challenges for Business Process Management and Electronic-Commerce. Journal of theoretical and applied electronic commerce research, 14(1): 1-3.

IFR. 2016. World Robotics Report 2016: European Union occupies top position in the global automation race. IFR. [Online]. Available at: https://ifr.org/ifr-press-releases/news/world-robotics-report-2016 [Accessed: 2019 May 15].

INSTITUT DER DEUTSCHEN WIRTSCHAFT CONSULT (IW Consult); FIR. 2015. Industrie 4.0 Readiness, commissioned by the IMPULS-Stiftung of the VDMA. Impuls. [Online]. Available at: http://www.impuls-stiftung.de/studien;jsessionid=D371AF8942274C06B６7E99721D269ED4 [Accessed: 15 June 2019].

KAZANCOGLU, Y. and OZKAN-OZEN, Y. D. 2018. Analyzing Workforce 4.0 in the Fourth Industrial Revolution and proposing a road map from operations management perspective with fuzzy DEMATEL. Journal of enterprise information management, 31(6): 891-907.

KOVACS, O. 2018. The dark corners of industry 4.0 - Grounding economic governance 2.0. Technology in Society, 55(3): 140-145.

KPMG. 2016. The Factory of the Future - Industry 4.0: The challenges of tomorrow. Available at: https:// assets.kpmg.com/content/dam/kpmg/pdf/2016/05/factory-future-industry-4.0.pdf [Accessed: 2019, June 13].

KRAFTOVA, I., DOUDOVA, I. and MILACEK, R. 2018. At the threshold of the fourth industrial revolution. Economics and Management, 3(21): 23-39.

LASI, H., FETTKE, P., KEMPER, H. G., FELD, T. and HOFFMANN, M. 2014. Industry 4.0. Business \& Information Systems Engineering, 6(4): 239-242.

LEZZI, M., LAZOI, M. and CORALLO, A. 2018. Cybersecurity for Industry 4.0 in the current literature: A reference framework. Computers in Industry, 103: 97-110.

LU, Y. 2017. Industry 4.0: A survey on technologies, applications and open research issues. Journal of Industrial Information Integration, 6: 1-10.

MANPOWERGROUP. 2017. Revolution of capabilities [in Czech: Revoluce dovedností. Available at: https://www.manpower.cz/manpower/wp-content/uploads/2017/01/revoluce-dovednosti.pdf [Accessed: 2019, June 13]. 
MASAROVA, T., KORDOA, M. and STRUNZ, H. 2018. The impact of Industry 4.0 initiative on labour market. In: Proceedings of International Scientific Conference ECONOMIC AND SOCIAL POLICY. 4-6 September 2018, Ostrava, Vysoká škola sociálně správní, pp. 221-230.

MITTAL, S., KHAN, M. A., ROMERO, D. and WUEST, T. 2018. A critical review of smart manufacturing \& Industry 4.0 maturity models: Implications for small and medium-sized enterprises (SMEs). Journal of manufacturing systems, 49: 194-214.

MINISTRY OF LABOUR AND SOCIAL AFFAIRS. 2016. Innitiative Industry 4.0 [in Czech: Iniciativa Průmysl 4.0]. Available at: http://www.mpo.cz/assets/dokumenty/53723/64358/658713/priloha001. pdf [Accessed: 2019, June 13].

MÜLLER, J. M. and DÄSCHLE, S. 2018. Business Model Innovation of Industry 4.0 Solution Providers Towards Customer Process Innovation. Processes, 6(12): 260.

NÁRODNÍ OBSERVATOŘ ZAMĚSTNANOSTI A VZDĚLÁVÁNÍ. 2017. Impacts of Industry 4.0 on the Czech Labor Market [in Czech: Dopady Průmyslu 4.0 na trh práce v ČR]. Available at: www.nvf.cz/cms/ assets/docs/.../794-0/dopady-prumyslu-4.0-na-trh-prace-v-cr.pdf [Accessed: 2019, June 14].

OECD. 2018. Transformative technologies and jobs of the future. Background report for the Canadian G7 Innovation Ministers' Meeting. Available at: https://www.oecd.org/innovation/transformativetechnologies-and-jobs-of-the-future.pdf [Accessed: 2019, June 15].

PICCAROZZI, M., AQUILANI, B. and GATTI, C. 2018. Industry 4.0 in Management Studies: A Systematic Literature Review. Sustainability, 10(10): 3821.

RODIC, B. 2017. Industry 4.0 and the new simulation modelling paradigm. Organizacija, 50(3): 193-207. RODRIGUEZ-SALVADOR, M. and MANCILLA-DE-LA-CRUZ, J. J. 2018. Presence of Industry 4.0 in additive manufacturing: technological trends analysis. DYNA, 93(6): 597-601.

RÜßSMANN, M., LORENZ, M., GERBERT, P., WALDNER, M., JUSTUS, J., ENGEL, P. and HARNISCH, M. 2015. Industry 4.0: The future of productivity and growth in manufacturing industries. Boston Consulting Group. [Online]. Available at: https://www.bcg.com/publications/2015/engineered_ products_project_business_industry_4_future_productivity_growth_manufacturing_industries. aspx [Accessed: 2019, June 13].

SEVINÇ, A., GÜR, Ş. and EREN, T. 2018. Analysis of the Difficulties of SMEs in Industry 4.0 Applications by Analytical Hierarchy Process and Analytical Network Process. Processes, 6(12): 264.

SHILLER, R. J. 2017. Robotization Without Taxation. Project Syndicate. [Online]. Available at: https:// www.project-syndicate.org/commentary/temporary-robot-tax-finances-adjustment-by-robert-j-shiller-2017-03?barrier=accesspaylog [Accessed: 2019, June 13]

STENTOFT, J., JENSEN, K. W., PHILIPSEN, K. and HAUG, A. 2019. Drivers and Barriers for Industry 4.0 Readiness and Practice: A SME Perspective with Empirical Evidence. In: Proceedings of the 52 Hawaii International Conference on System Sciences, pp. 5155-5164.

SUMER, B. 2018. Impact of Industry 4.0 on Occupations and Employment in Turkey. European Scientific Journal, ESJ, 14(10): 1-17.

SYAM, N. and SHARMA, A. 2018. Waiting for a sales renaissance in the fourth industrial revolution: Machine learning and artificial intelligence in sales research and practice. Industrial Marketing Management, 69: 135-146.

WILKESMANN, M. and WILKESMANN, U. 2018. Industry 4.0 - organizing routines or innovations? VINE Journal of Information and Knowledge Management Systems. 48(2): 238-254.

WORLD ECONOMIC FORUM. 2016. The Industry Gender Gap: Women and Work in the Fourth Industrial Revolution. Available at: http://www3.weforum.org/docs/WEF_FOJ_Executive_Summary_ GenderGap.pdf [Accessed: 2019, June 10].

Contact information

Nikola Soukupová: nsoukupova@ef.jcu.cz

Markéta Adamová: adamovam@ef.jcu.cz

Růžena Krninská: krninska@ef.jcu.cz 